\title{
Identification and antimicrobial activity of Micromonospora strains from Thai peat swamp forest soils
}

\author{
Chitti Thawai ${ }^{1}$, Pawina Kanchanasin², Moriya Ohkuma ${ }^{3}$, Takuji Kudo ${ }^{3}$, Somboon Tanasupawat ${ }^{2 *}$ \\ ${ }^{1}$ Department of Biology, Faculty of Science, King Mongkut's Institute of Technology Ladkrabang, Bangkok 10520, Thailand. \\ ${ }^{2}$ Department of Biochemistry and Microbiology, Faculty of Pharmaceutical Sciences, Chulalongkorn University, Bangkok 10330, Thailand. \\ ${ }^{3}$ Japan Collection of Microorganisms, RIKEN BioResource Center, 3-1-1 Koyadai, Tsukuba, Ibaraki 305-0074, Japan.
}

\section{ARTICLE INFO \\ Article history: \\ Received on: 10/01/2018 \\ Accepted on: 14/02/2018 \\ Available online: 29/04/2018}

\section{Key words:}

Actinomycetes, antimicrobial activity, Thai

peat swamp forest, soils,

Micromonospora.

\begin{abstract}
The identification and antimicrobial activity of thirteen actinomycete strains isolated from peat swamp forest soils collected from Narathiwat, Patthaloong and Yala provinces, the southern part of Thailand were carried out. Based on the phenotypic and chemotaxonomic characteristics, all isolates were belonged to genus Micromonospora. They were separated into six groups based on 16S ribosomal RNA gene sequence analysis and were identified as M. narathiwatensis (Group 1, 5 isolates), M. humi (Group 4, 3 isolates), M. aurantiaca (Group 5, 2 isolates), one of each isolate as M. chalcea (Group 2) and M. maritima (Group 6). The isolate LK6-12 (Group 3) showed low similarity $(99.16 \%)$ with the type strains of Micromonospora siamensis that will be the novel species of the genus Micromonospora. Meso-diaminopimelic acid (cell wall type II), xylose and arabinose (pattern D) were detected in their whole-cell hydrolysates. The major polar lipid was phosphatidylethanolamine (type II). The predominant cellular fatty acids were $\mathrm{C}_{17: 0}, \mathrm{C}_{17: 1} \omega 8 \mathrm{c}$, iso- $\mathrm{C}_{16: 0}$, iso- $\mathrm{C}_{15: 0}$, iso- $\mathrm{C}_{17: 0}$, anteiso- $\mathrm{C}_{15: 0}$, and anteiso- $\mathrm{C}_{17: 0}$. The predominant menaquinones were MK-9 $\left(\mathrm{H}_{4}\right)$, MK-9 $\left(\mathrm{H}_{6}\right)$, or MK-10 $\left(\mathrm{H}_{4}\right)$. The DNA G+C contents of the isolates ranged from 71.6$72.6 \mathrm{~mol} \%$. On the primary screening, 2 isolates exhibited the antimicrobial activity against Bacillus subtilis ATCC 6633 and Kocuria rhizophila ATCC 9341.
\end{abstract}

\section{INTRODUCTION}

Micromonospora strains are Gram-positive, aerobic, mesophilic, non-motile actinomycete which produces single non-motile spore directly from substrate hyphae and their mycelial pigments generally are in orange, red or brown color. Cell wall contained meso-diaminopimelic acid, glutamic acid, glycine, alanine, and glycolylmuramic acid. The diagnostic whole-cell sugars were xylose and arabinose. The phospholipid patterns were diphosphatidylglycerol, phosphatidylinositol, phosphatidylethanolamine, and phosphatidylinositolmannosides, but not phosphatidylcholine. Predominant cellular fatty acids were iso- $\mathrm{C}_{16: 0}$ and iso- $\mathrm{C}_{15: 0}$ and small amount of iso- $\mathrm{C}_{17: 0}$, anteiso- $\mathrm{C}_{17: 0}$

\footnotetext{
"Corresponding Author

Somboon Tanasupawat; Department of Biochemistry and Microbiology,

Faculty of Pharmaceutical Sciences, Chulalongkorn University, 254

Phayathai Road, Wangmai, Bangkok 10330, Thailand.

E-mail:Somboon.T@chula.ac.th
}

and anteiso- $\mathrm{C}_{150}$ were also present. The major menaquinones were MK-9, MK-10, and MK-12. The range of $\mathrm{G}+\mathrm{C}$ content of the DNA was 71-73 mol\% (Kawamoto, 1989; Kasai et al., 2000).

Micromonospora strains have been reported to distribute in different environments such as in soils, sandstone, water, root nodules and mangrove sediment (Kawamoto, 1989; Hirsch et al., 2004; Ara and Kudo, 2007; Trujillo et al., 2007; Huang et al., 2008; Garcia et al., 2010; Wang et al., 2011). In addition, the novel species of M. auratinigra, M. eburnea, M. narathiwatensis, $M$. chaiyaphumensis, M. krabiensis, M. marina, M. humi, M. maritima and M. sediminis strains are isolated (Thawai et al., 2005a; 2007; 2008; Jongrungruangchok et al. 2008; Tanasupawat et al., 2010; Songsumanus et al., 2013; Phongsopitanun et al., 2016) were reported in Thailand. These actinomycetes are potential producers for secondary metabolites with diverse chemical structures, and biological activities, e.g. gentamicin (a considered essential to global health), sagamicin, megalomicin, halomicin, mutamicin, everninomicin, and mycinamicin (Glasby, 1993). 
Peat swamp forest is a very special type of the evergreen forests that occurs in fresh-water marshy land (Posa et al., 2011) and was an interested source for soil sampling because it was different from the normal soil. Nowadays, Micromonospora strains from tropical peat swamp forests are still limited in isolation and the research on taxonomy and antibiotic production of them have so far received little attention. Thus, the attempt to sampling the soil samples in the unique sources is focused. In this study, Micromonospora strains isolated from peat swamp forest soils in the southern areas of Thailand were characterized and identified by both classical and molecular techniques, and the investigation of antimicrobial activity is also performed.

\section{MATERIALS AND METHODS}

\section{Isolation and identification of isolates}

Micromonospora strains were isolated from 11 soil samples (peat, muck) collected from peat swamp forest in Narathiwat, Patthaloong and Yhala provinces, the southern areas of Thailand. The soil suspension was diluted to a ten folds dilution series $\left(10^{-1}\right.$ to $\left.10^{-3}\right)$. The aliquots $(100 \mu \mathrm{L})$ were spread onto Starch-Casein Nitrate agar (SCA) plates supplemented with antibiotics, nystatin, novobiocin, and tetracycline (Brock et al., 1993), and were incubated at $30^{\circ} \mathrm{C}$ for $7-21$ days. The moist, pale yellow, orange, brown and black colonies of isolates were picked up and streaked for purification on ISP2 agar plates at $30^{\circ} \mathrm{C}$ for 7-21 days. The single colony was cultivated on ISP2 agar slants at $30^{\circ} \mathrm{C}$ for 14 days. The soil samples were dried under room temperature for a week. Dried soil ( $1 \mathrm{~g})$ was put into a test tube which then $2.5 \mathrm{~mL}$ of distilled water was added and shaked for 30 sec. The soil solution was measured for $\mathrm{pH}$ value.

The morphological characteristics of Micromonospora isolates were determined by using simple inclined coverslip technique (Williams and Cross, 1971). Cultural characteristics were studied on the colors of mature substrate mycelium, spore, and diffusible pigment using crosshatch streak (Shirling and Gottlieb, 1966). The strains were cultivated on yeast extract malt extract agar (International Streptomyces Project, ISP2 medium) at $30^{\circ} \mathrm{C}$ for 21 days. The color of the upper and reverse surface mycelium and the soluble pigment color were observed by using the NBS/ISCC colour system (Kelly, 1964). Spore was observed by light microscope or scanning electron microscope. Utilization of various carbon sources and several biochemical tests were determined using standard methods as recommended by Shirling and Gottlieb (1966) and Arai (1975). NaCl tolerance was tested on ISP2 agar plates supplemented with 1.5, 3, 4, 5, 6 or $7 \%(\mathrm{w} / \mathrm{v}) \mathrm{NaCl}$. Growth at 30, 40, and $45^{\circ} \mathrm{C}$, at $\mathrm{pH} 4,4.5$, $5,6,7$, and 8 were performed on ISP2 agar plates, incubated for 7-14 days. Standard thin-layer chromatography (TLC) procedures were used to determine the isomers of diaminopimelic acid and sugars in whole-cell hydrolysates (Staneck and Roberts, 1974). The $N$-acyl type of muramic acids in the cell wall was determined as described by Uchida and Aida (1984). Menaquinones were extracted as reported by Collins et al. (1977) and analysed using high-performance liquid chromatography (HPLC). Cellular fatty acids methyl esters were prepared as described by Sasser (1990) and were analysed using gas chromatography according to the instructions of the Sherlock Microbial Identification
System (MIDI). Polar lipids were extracted and analysed by twodimensional TLC (Minnikin et al. 1984).

\section{S rRNA gene sequence and phylogenetic analyses}

The genomic DNA of Micromonospora isolates was extracted from the cultures grown in yeast extract-glucose broth on a rotary shaker as described by Tamaoka and Komagata (1984). The DNA G $+\mathrm{C}$ content was determined by reversed phase HPLC (Tamaoka and Komagata, 1984). The 16S rRNA gene was amplified using the universal primers 27F [5'-AGAGTTTGATC(AC) TGGCTCAG-3'] and 1492R [5'-ACGG(CT)TACCTTG TTACGACTT-3'] as described by Weisburg et al. (1991). The PCR products were sequenced using universal primers (Lane, 1991). The closest phylogenetic neighbours were identified by BLAST searches using the EzBioCloud database (www. ezbiocloud.net/) (Yoon et al., 2017). The 16S rRNA gene sequence was manually verified and multiple-aligned with selected sequences. Phylogenetic tree was generated using the neighbour-joining (Saitou and Nei, 1987) in the MEGA 6.0 software (Tamura et al., 2013). Gaps and ambiguous nucleotides were completely eliminated before the calculations. Evolutionary distances among the strains were analysed based on Kimura's two-parameter method (Kimura, 1980) for neighbour-joining tree. The confidence values of nodes were evaluated by the bootstrap resampling method with 1000 replications (Felsenstein, 1985).

\section{Screening of antimicrobial activity of isolates}

Each isolate was cultured in $50 \mathrm{~mL}$ of seed medium conposing of glucose $(0.4 \%)$, yeast extract $(0.4 \%)$, malt extract (1.0\%), pH 7.3 (in a $250 \mathrm{~mL}$ Erlenmeyer flask) and cultivated on shaker $(200 \mathrm{rpm})$ at room temperature for 4 days. One percent of seed culture was transferred into $200 \mathrm{~mL}$ of production medium which comprised glucose $(0.4 \%)$, yeast extract $(0.4 \%)$, malt extract $(1.0 \%)$, and $\mathrm{CaCO}_{3}(0.1 \%), \mathrm{pH} 7.3$, incubated on a rotary shaker $(200 \mathrm{rpm})$ at room temperature for 10 days. The antimicrobial activity of the isolated fractions was examined by the agar disc diffusion method (Acar and Goldstein, 1991) against Staphylococcus aureus ATCC 25923, Bacillus subtilis ATCC 6633, Escherichia coli ATCC 25922, Kocuria rhizophila ATCC 9341, Pseudomonas aeruginosa ATCC 27853, and Candida albicans ATCC 10231 on Mueller-Hinton agar plates at $37^{\circ} \mathrm{C}$ for $24 \mathrm{~h}$, but the yeast strain was cultivated on Sabouraud's dextrose agar plates at $30^{\circ} \mathrm{C}$ for $24 \mathrm{~h}$.

\section{RESULTS AND DISCUSSION}

\section{Isolation and identification of isolates}

The actinomycete strains, BTG1-1, KM1-9, BTG2-3, LK2-6, BTG3-4, LK5-4, LK6-12, KM4-24, BTG7-3, BTG102, BTG3-2, KM3-14 and KM3-1 were isolated from 11 samples of peat swamp forest soils in Narathiwat, Pattaloong and Yala provinces, Thailand (Table 1). The $\mathrm{pH}$ of the soil samples ranged from 3.39-6.37. They produced single non-motile spores on the substrate hyphae. Aerial mycelium was absent. All were aerobic, Gram-positive, aerobic, mesophilic, non-motile actinomycete. They grew well at $\mathrm{pH} 5-8$ and at $25-30^{\circ} \mathrm{C}$ but did not grow at above $40^{\circ} \mathrm{C}$. All isolates liquefied gelatin (Table 2). Their cell wall contained glutamic acid, glycine, alanine, meso-diaminopimlic 
acid and xylose and arabinose as whole-cell sugars. The $N$-acyl group of muramic acid in the cell wall was glycolyl type. Hydrolysis of starch and milk peptonization were positive. They contained diphosphatidylglycerol, phosphatidylinositolmannosides, phosphatidylinositol and phosphatidylethanolamine, but not phosphatidylcholine as phospholipid profiles. On the basis of their morphological, cultural, physiological, biochemical and chemotaxonomic characteristics including the 16S rRNA gene sequence analysis, 13 isolates were divided into 6 groups as described below.

Table 1: Isolate number, sources of isolation, $\mathrm{pH}$ of soil, cultural characteristics, similarity (\%) of 16S rRNA gene sequence similarity and identification of Micromonospora strains.

\begin{tabular}{|c|c|c|c|c|c|c|c|c|c|}
\hline $\begin{array}{l}\text { Isolate } \\
\text { No. }\end{array}$ & Sources & Province & $\begin{array}{l}\text { Soil } \\
\text { pH }\end{array}$ & Group & Upper surface color & Reverse surface color & $\begin{array}{l}\text { Soluble pigment } \\
\text { color }\end{array}$ & $\%$ similarity & Identification \\
\hline BTG1-1 & Peat & Narathiwat & 3.44 & 1 & Black & Dull orange & Pale yellow & 100.00 & M. narathiwatensis \\
\hline KM1-9 & Muck & Patthaloong & 4.92 & 1 & Dull orange & Dull orange & Pale yellow & 100.00 & M. narathiwatensis \\
\hline BTG2-3 & Peat & Narathiwat & 3.39 & 1 & $\begin{array}{l}\text { Black strong yellowish } \\
\text { orange }\end{array}$ & $\begin{array}{l}\text { Grayish yellow strong } \\
\text { yellowish orange }\end{array}$ & Pale yellow & 100.00 & M. narathiwatensis \\
\hline LK2-6 & Soil & Yala & 6.37 & 1 & Yellowish brown & Pale yellowish pink & Pale yellow & 100.00 & M. narathiwatensis \\
\hline BTG3-4 & Muck & Narathiwat & 4.25 & 1 & Black & Grayish yellow & Pale yellow & 99.79 & M. narathiwatensis \\
\hline LK5-4 & Muck & Yala & 4.36 & 2 & Black & Deep orange & - & 99.71 & M. chalcea \\
\hline LK6-12 & Peat & Yala & 4.64 & 3 & Dark grayish brown & Deep orange & Pale yellow & 99.16 & M. siamensis \\
\hline KM4-24 & Peat & Patthaloong & 3.41 & 4 & Deep orange & Deep orange & Pale yellow & 100.00 & M. humi \\
\hline BTG7-3 & Soil & Narathiwat & 4.05 & 4 & Dark grayish brown & Vivid orange & Pale yellow & 99.72 & M. humi \\
\hline BTG10-2 & Soil & Narathiwat & 4.29 & 4 & Vivid orange & Vivid orange & Pale yellow & 99.72 & M. humi \\
\hline BTG3-2 & Muck & Narathiwat & 4.25 & 5 & Brownish black to black & Deep orange & - & 100.00 & M. aurantiaca \\
\hline KM3-14 & Soil & Patthaloong & 4.16 & 5 & Dark yellowish brown & Light yellowish & - & 100.00 & M. aurantiaca \\
\hline KM3-1 & Soil & Patthaloong & 4.16 & 6 & $\begin{array}{l}\text { Dark brown to brownish } \\
\text { black }\end{array}$ & Deep orange & Yellow & 99.79 & M. maritima \\
\hline
\end{tabular}

Table 2: Characteristics of Miromonospora strains.

\begin{tabular}{|c|c|c|c|c|c|c|}
\hline \multirow{2}{*}{ Characteristics } & \multicolumn{6}{|c|}{ Group } \\
\hline & 1 & 2 & 3 & 4 & 5 & 6 \\
\hline No. of isolate & 5 & 1 & 1 & 3 & 2 & 1 \\
\hline Gelatin liquefaction & $+(\mathrm{w} 1)$ & + & w & $+(\mathrm{w} 1)$ & + & + \\
\hline Milk peptonization & $\mathrm{w}(+2)$ & + & w & + & + & + \\
\hline Milk coagulation & $+(-1)$ & + & - & + & + & + \\
\hline Starch hydrolysis & + & + & + & + & $\mathrm{w}$ & + \\
\hline Nitrate reduction & $-(w 2)$ & + & - & - & + & w \\
\hline $\mathrm{NaCl}$ tolerance $(\%)$ & $\leq 3$ & $\leq 6$ & $\leq 4$ & $\leq 4$ & $\leq 4$ & $\leq 5$ \\
\hline \multicolumn{7}{|l|}{ Carbon utilization } \\
\hline L-Arabinose & $-(w 1)$ & - & - & - & $\mathrm{w}$ & - \\
\hline Cellobiose & $-(+2)$ & + & $\mathrm{w}$ & $+(\mathrm{w} 1)$ & + & + \\
\hline D-Fructose & $-(w 1)$ & $\mathrm{w}$ & - & - & + & $\mathrm{w}$ \\
\hline D-Galactose & $-(+2)$ & + & - & $+(-1)$ & + & + \\
\hline Glycerol & $\mathrm{w}(-2)$ & $\mathrm{w}$ & + & $\mathrm{w}(+1)$ & - & + \\
\hline Lactose & $\mathrm{w}(-2)$ & + & $\mathrm{w}$ & + & - & + \\
\hline D-Mannitol & $\mathrm{w}(-2)$ & $\mathrm{w}$ & + & $+(-)$ & - & w \\
\hline D-Melibiose & $+(-1)$ & + & - & + & + & + \\
\hline D-Raffinose & + & + & + & + & $+(\mathrm{w} 1)$ & $\mathrm{w}$ \\
\hline L-Rhamnose & $-(+2)$ & $\mathrm{w}$ & $\mathrm{w}$ & $+(\mathrm{w} 1)$ & - & + \\
\hline D-Ribose & $-(+2)$ & - & - & - & - & - \\
\hline Salicin & $+(\mathrm{w} 2)$ & - & + & $-(+1)$ & - & $\mathrm{w}$ \\
\hline D-Xylose & + & + & + & + & + & + \\
\hline \multicolumn{7}{|l|}{ Antibacterial activity } \\
\hline B. subtilis ATCC 6633 & - & - & - & + & - & - \\
\hline K. rhizophila ATCC 9341 & - & - & - & + & - & - \\
\hline Major menaquinones & $\begin{array}{c}\left.\text { MK-10 }\left(\mathrm{H}_{8}\right), \text { MK-10( } \mathrm{H}_{6}\right), \\
\left.\text { MK-10( } \mathrm{H}_{4}\right)\end{array}$ & $\begin{array}{l}\text { MK-10( }\left(\mathrm{H}_{4}\right) \\
\left.\text { MK-10( } \mathrm{H}_{6}\right)\end{array}$ & $\begin{array}{c}\left.\text { MK-10 }\left(\mathrm{H}_{4}\right), \text { MK-10( } \mathrm{H}_{6}\right), \\
\text { MK- } 9\left(\mathrm{H}_{4}\right)\end{array}$ & $\begin{array}{l}\text { MK-10( }\left(\mathrm{H}_{4}\right), \\
\left.\text { MK-10( } \mathrm{H}_{6}\right)\end{array}$ & $\begin{array}{c}\text { MK-10( }\left(\mathrm{H}_{4}\right) \\
\text { MK-9( }\left(\mathrm{H}_{4}\right)\end{array}$ & MK-10( $\left.\mathrm{H}_{4}\right), \mathrm{MK}-10\left(\mathrm{H}_{6}\right)$ \\
\hline $\mathrm{G}+\mathrm{C}(\mathrm{mol} \%)$ & 71.6 & 72.3 & 72.6 & 72.5 & 72.4 & ND \\
\hline
\end{tabular}

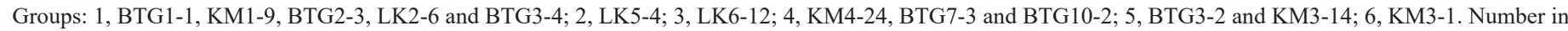

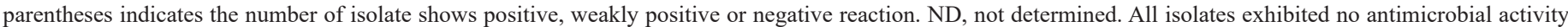
against E. coli ATCC 25922, P. aeruginosa ATCC 27853, S. aureus ATCC 25923 and C albicans ATCC 10231. 
Group 1 comprised five isolates, BTG1-1, KM1-9, BTG2-3, LK2-6 and BTG3-4. Colonies were grayish yellow on ISP2 medium, turning to black after sporulation. Single spores are formed on the substrate hyphae (Figure 2). They utilized D-glucose, D-melibiose, D-raffinose, salicin and D-xylose. Growth occured in the presence of $\mathrm{NaCl}$ up to $3 \%$. The predominant cellular fatty acids were $\mathrm{C}_{17: 0}, \mathrm{C}_{17: 1} \omega 8 \mathrm{c}$, iso- $\mathrm{C}_{15: 0}$, anteiso- $\mathrm{C}_{15: 0}$, iso- $\mathrm{C}_{16: 0}$ and iso$\mathrm{C}_{17: 0}$ were also present (Table 3). MK-10 $\left(\mathrm{H}_{8}\right), \mathrm{MK}-10\left(\mathrm{H}_{6}\right)$ and
MK-10( $\left.\mathrm{H}_{4}\right)$ were major menaquinone components. The DNA G+C content of strain BTG2-3 was $71.6 \mathrm{~mol} \%$. The BLAST analysis of 16S rRNA gene sequence of strains BTG1-1, KM1-9, BTG2-3, LK2-6 and BTG3-4 indicated that the strains were closely related to Micromonospora narathiwatensis (99.79-100\% similarity) as shown in Table 1. Phylogenetic analysis of strains BTG1-1, KM1-9, BTG2-3, LK2-6 and BTG3-4 revealed that they were identified as M. narathiwatensis (Thawai et al., 2007) (Figure 1).

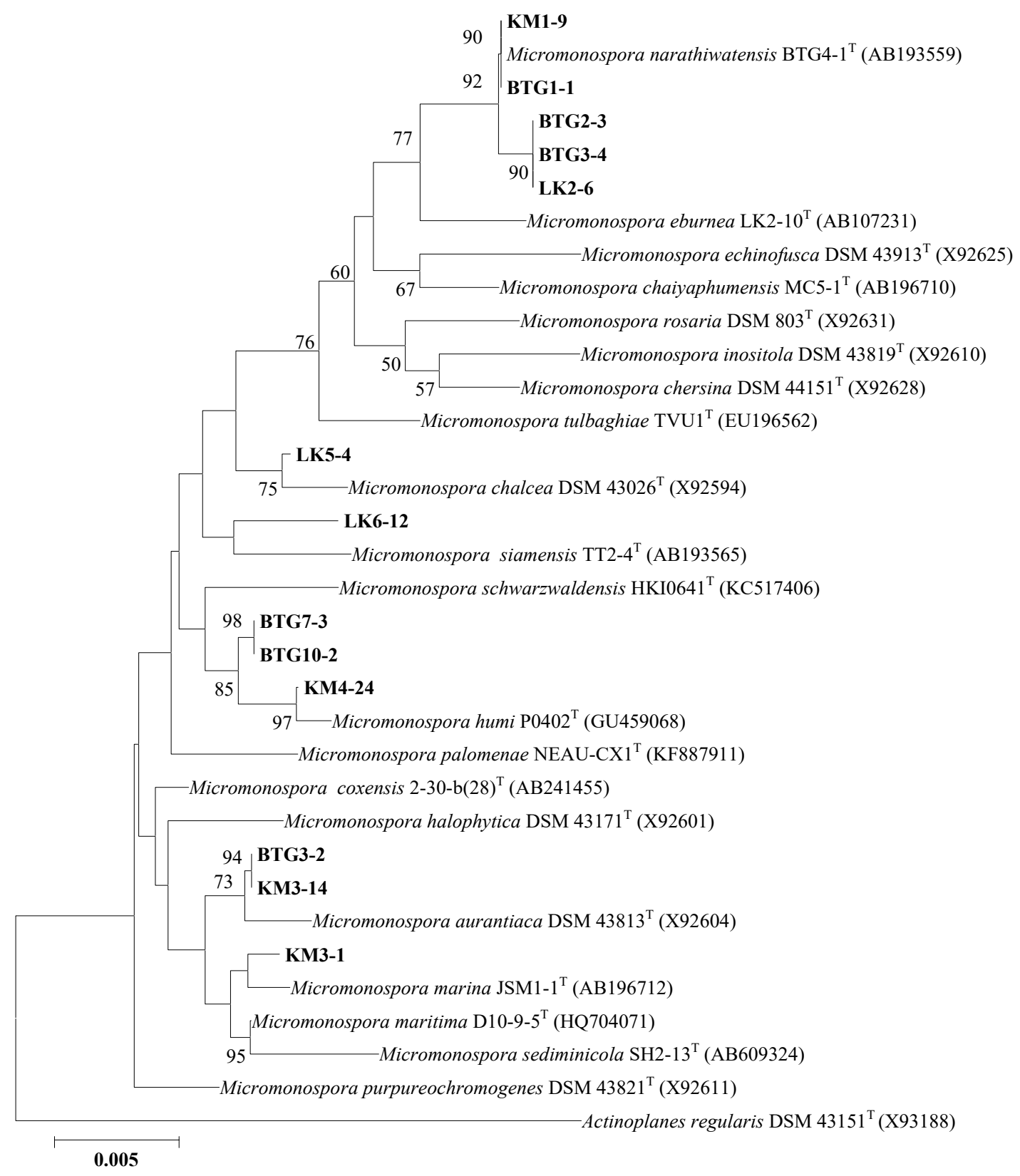

Fig. 1: Neighbour-joining tree based on distance analysis representing relationship between the partial 16S rRNA gene sequences of 13 Micromonospora isolates and the nearest relatives obtained from EzTaxon.

Group 2 contained one isolate, LK5-4. Colonies were deep orange in ISP2 medium, turning to black after sporulation. They utilized D-glucose, D-melibiose, D-mannitol, Draffinose, L-rhamnose, glycerol, lactose, D-galactose, cellobiose, D-fructose, and D-xylose, but not salicin, L-arabinose, and D-ribose. Nitrate reduction was positive. This strain grew on $6 \% \mathrm{NaCl}$ concentration. The predominant cellular fatty acids were iso- $\mathrm{C}_{16: 0}$, anteiso- $\mathrm{C}_{17: 0}$, iso- $\mathrm{C}_{15: 0}$ and 10-Methyl $\mathrm{C}_{17: 0}$, and a small amount of 
iso- $\mathrm{C}_{17: 0}$ and anteiso- $\mathrm{C}_{15: 0}$. $\mathrm{MK}-10\left(\mathrm{H}_{4}\right)$, and $\mathrm{MK}-10\left(\mathrm{H}_{6}\right)$ were major menaquinones. The DNA G+C content of strain was $72.3 \mathrm{~mol} \%$. The BLAST analysis of 16S rRNA gene sequence of strain LK5-4 indicated that the strain was closely related to Micromonospora chalcea (99.71\% similarity) as shown in Table 1 . Phylogenetic analysis of strain LK5-4 revealed that it was identified as $M$. chalcea (Kawamoto, 1989) (Figure 1).

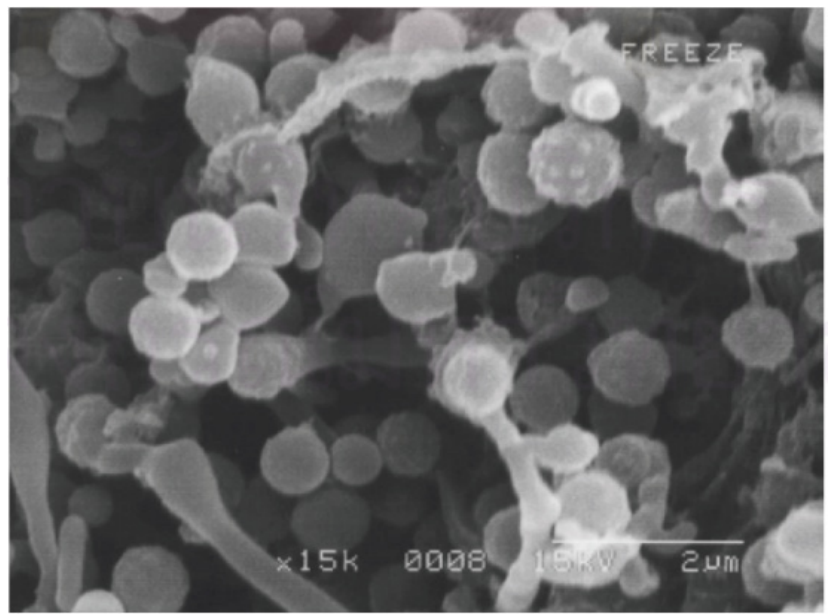

Fig. 2: The scanning electron micrograph of strain BTG 2-3 on ISP2 medium (21 days).

Table 3: Cellular fatty acid profiles of Miromonospora strains.

\begin{tabular}{|c|c|c|c|c|c|c|}
\hline \multirow{2}{*}{ Fatty acid } & \multicolumn{6}{|c|}{ Group } \\
\hline & 1 & 2 & 3 & 4 & 5 & 6 \\
\hline \multicolumn{7}{|l|}{ Saturated fatty acids } \\
\hline $\mathrm{C}_{15: 0}$ & 2.8 & - & 1.9 & $3.3-9.7$ & - & - \\
\hline $\mathrm{C}_{16: 0}$ & 1.7 & - & 2.4 & $1.4-1.9$ & 0.7 & 0.9 \\
\hline $\mathrm{C}_{17: 0}$ & 7.7 & 0.8 & 4 & $9.2-9.8$ & 2.8 & 1.7 \\
\hline $\mathrm{C}_{18: 0}$ & 1 & 1.6 & 1.8 & $0.5-0.7$ & 1.2 & 1.6 \\
\hline \multicolumn{7}{|l|}{ Unsaturated fatty acids } \\
\hline $\mathrm{C}_{17: 1} \omega 8 \mathrm{c}$ & 6.9 & 2.7 & 9.5 & $11.4-14$ & 8.7 & 6.4 \\
\hline$C_{18: 1} \omega 7 \mathrm{c}$ & - & - & 0.7 & - & - & - \\
\hline $\mathrm{C}_{18: 1} \omega 9 \mathrm{c}$ & 0.7 & 4.5 & 4.3 & 0.7 & 4.7 & 4.9 \\
\hline \multicolumn{7}{|l|}{ Branched fatty acids } \\
\hline iso- $\mathrm{C}_{14: 0}$ & 1 & 1.6 & 0.9 & $2.5-7.7$ & 0.5 & 0.5 \\
\hline iso- $\mathrm{C}_{15: 0}$ & 42.4 & 5.6 & 18.6 & $11.6-20.4$ & 18.8 & 25.4 \\
\hline anteiso- $\mathrm{C}_{15: 0}$ & 10.3 & 4.3 & 6 & $9.3-16.1$ & 10.3 & 6.4 \\
\hline iso- $\mathrm{C}_{16: 0}$ & 11.5 & 45.4 & 18.2 & $17.9-23.1$ & 13.3 & 14.7 \\
\hline iso- $\mathrm{C}_{17: 0}$ & 5.3 & 2.5 & 5.2 & $0.6-2.3$ & 8 & 10.4 \\
\hline anteiso- $\mathrm{C}_{17: 0}$ & 4.6 & 9.6 & 7.7 & $1.7-4.4$ & 14.2 & 10.8 \\
\hline \multicolumn{7}{|l|}{$\begin{array}{l}\text { 10-Methylated fatty } \\
\text { acids }\end{array}$} \\
\hline 10-Methyl $C_{17: 0}$ & 1.1 & 7.4 & 1.4 & $2.1-2.8$ & 1.2 & 1.4 \\
\hline 10-Methyl $\mathrm{C}_{18: 0}$ TBSA & - & 1.5 & - & - & 1.3 & 0.5 \\
\hline Summed feature $3^{\mathrm{a}}$ & 0.9 & 0.5 & 1.6 & $0.7-0.8$ & 0.9 & 1.2 \\
\hline Summed feature $6^{\mathrm{b}}$ & - & - & - & - & 0.5 & - \\
\hline
\end{tabular}

Group1: LK2-6; 2, LK5-4; 3, LK6-12; 4, KM4-24 and BTG10-2; 5, BTG3-2; 6, KM3-1. -, not detected. ${ }^{\text {aS }}$, following fatty acids: $2-\mathrm{OH}-\mathrm{i}-\mathrm{C}_{15: \mathrm{o}}$ and/or $\mathrm{C}_{16: 1} \omega 7 \mathrm{c}$. ${ }^{\mathrm{b}} \mathrm{S}$ ummed feature 6 contained one or more of the following fatty acid: $\mathrm{C}_{19: 1} \omega 11 \mathrm{c} / \mathrm{C}_{19: 1} \omega 9 \mathrm{c}$.
Group 3 contained one isolate, LK6-12. Colonies were deep orange in ISP2, turning to dark grayish brown after sporulation. The spore surface appeared rough (Figure 3). Pale yellow soluble pigment is produced on ISP2 medium. The strain LK6-12 utilized D-glucose, D-raffinose, salicin, lactose, glycerol, D-mannitol, L-rhamnose, cellobiose and D-xylose but not D-melibiose, D-galactose, L-arabinose, D-ribose and D-fructose. Nitrate reduction was negative. This strain grew on $4 \% \mathrm{NaCl}$ concentration. The predominant cellular fatty acids were iso- $\mathrm{C}_{15: 0}$, iso- $\mathrm{C}_{16: 0}$, iso- $\mathrm{C}_{17: 0}, \mathrm{C}_{17: 1} \omega 8 \mathrm{c}$, anteiso- $\mathrm{C}_{15: 0}$ and anteiso- $\mathrm{C}_{17: 0}$. Major menaquinones were MK-10 $\left(\mathrm{H}_{4}\right), \mathrm{MK}-10\left(\mathrm{H}_{6}\right)$ and MK-9 $\left(\mathrm{H}_{4}\right)$. The DNA $\mathrm{G}+\mathrm{C}$ content was $72.6 \mathrm{~mol} \%$. The BLAST analysis of $16 \mathrm{~S}$ rRNA gene sequence of strain LK6-12 indicated that the strain was closely related to Micromonospora siamensis (99.16\% similarity) (Thawai et al., 2005b) and showed low similarity that will be the novel species of the genus Micromonospora (Figure 1).

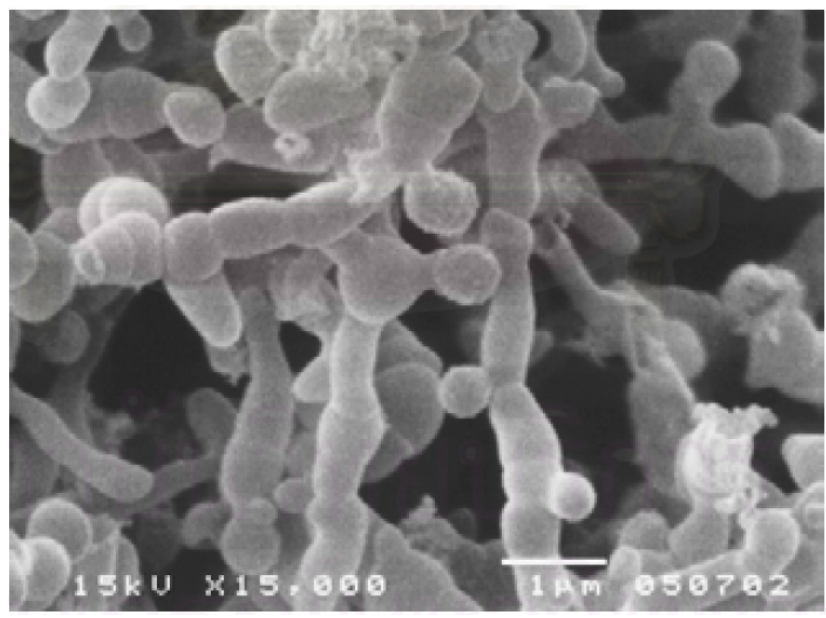

Fig. 3: The scanning electron micrograph of strain LK6-12 on YMA medium (21 days).

Group 4 comprised of three isolates, KM4-24, BTG7-3 and BTG10-2. Colonies were vivid orange on ISP2 medium. The spores surface appeared smooth (Figure 4). Pale yellow soluble pigment was produced on ISP2 medium. They utilized D-glucose, D-melibiose, D-raffinose, lactose, glycerol, L-rhamnose, cellobiose and D-xylose. Nitrate reduction was negative. This strain grew on $4 \% \mathrm{NaCl}$ concentration. The major cellular fatty acids were $\mathrm{C}_{17: 0}, \mathrm{C}_{17: 1} \omega 8 \mathrm{c}$, iso- $\mathrm{C}_{15: 0}$, anteiso- $\mathrm{C}_{15: 0}$ and iso- $\mathrm{C}_{16: 0}$. MK-10 $\left(\mathrm{H}_{4}\right)$ and $\mathrm{MK}-10\left(\mathrm{H}_{6}\right)$ were the predominant menaquinones. The DNA G+C content of strain BTG10-2 was $72.5 \mathrm{~mol} \%$. The strain BTG7-3 and BTG10-2 produced secondary metabolites that could inhibit growth of Bacillus subtilis ATCC 6633 and Kocuria rhizophila ATCC 9341. The BLAST analysis of 16S rRNA gene sequence of strains KM4-24, BTG7-3 and BTG10-2 indicated that the strains were closely related to $M$. humi $(99.72-100 \%$ similarity) as shown in Table 1. Phylogenetic analysis of strains KM4-24, BTG7-3 and BTG10-2 revealed that they were belonged to M. humi (Songsumanus et al., 2011) (Figure 1).

Group 5 consisted of two isolates, BTG3-2 and KM314. Colonies are light yellowish brown in ISP2, turning to dark yellowish brown after sporulation. They utilized D-melibiose, D-glucose, D-raffinose, D-galactose, cellobiose, D-fructose, 
and D-xylose, but not D-mannitol, L-rhamnose, glycerol, lactose, salicin, L-arabinose, and D-ribose. Nitrate reduction is positive. Growth occured in the presence of $\mathrm{NaCl}$ up to $4 \%$. The predominant cellular fatty acids contained $\mathrm{C}_{17: 1} \omega 8 \mathrm{c}$, iso- $\mathrm{C}_{15: 0}$, anteiso- $\mathrm{C}_{15: 0}$, iso- $\mathrm{C}_{16: 0}$, iso- $\mathrm{C}_{17: 0}$, and anteiso- $\mathrm{C}_{17: 0}$. The predominant menaquinones of all isolates are $\mathrm{MK}-10\left(\mathrm{H}_{4}\right)$, and $\mathrm{MK}-9\left(\mathrm{H}_{4}\right)$. The DNA G+C content of strain KM3-14 was $72.4 \mathrm{~mol} \%$. The BLAST analysis of 16S rRNA gene sequence of strains BTG3-2 and KM3-14 indicated that the strains were closely related to $M$. aurantiaca (100\% similarity) as shown in Table 1. Phylogenetic analysis of strains BTG3-2 and KM3-14 revealed that they were belonged to M. aurantiaca (Sveshnikova et al., 1969) (Figure 1).

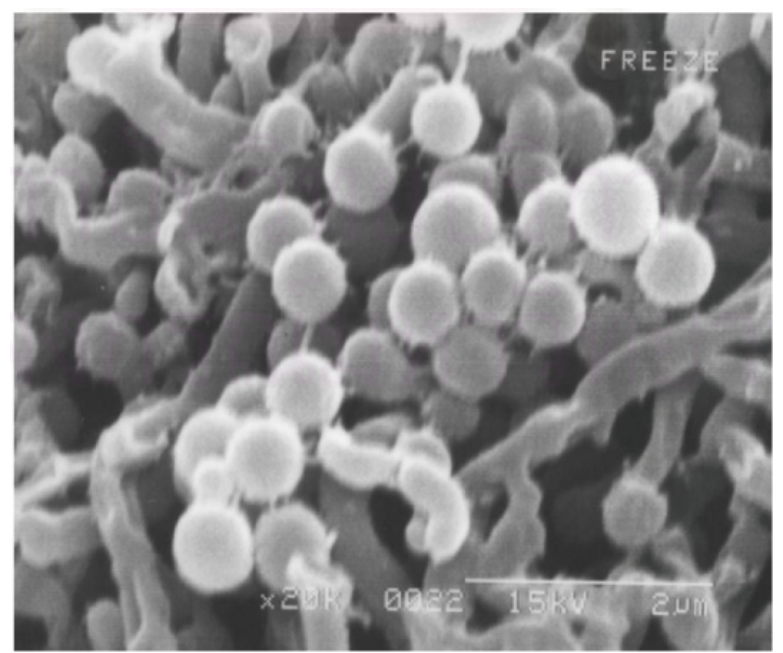

Fig. 4: The scanning electron micrograph of strain BTG10-2 on ISP2 medium (21 days).

Group 6 contained one isolates, including KM3-1. Colonies are deep orange and turning to black after sporulation. The strain KM3-1 utilized D-mannitol, D-raffinose, L-rhamnose, glycerol, lactose, D-galactose, D-fructose, cellobiose, D-melibiose, D-glucose, and D-xylose, but not salicin, L-arabinose, and D-ribose. Nitrate reduction is weak positive. Growth occured in the presence of $\mathrm{NaCl}$ up to $5 \%$. The major cellular fatty acids were $\mathrm{C}_{17: 1} \omega 8 \mathrm{c}$, iso- $\mathrm{C}_{15: 0}$, iso- $\mathrm{C}_{16: 0}$, iso- $\mathrm{C}_{17: 0}$, anteiso- $\mathrm{C}_{15: 0}$ and anteiso- $\mathrm{C}_{17: 0}$, and a small amount of iso- $\mathrm{C}_{17: 0}$, and anteiso- $\mathrm{C}_{15: 0}$ are also present. The predominant menaquinones were $\mathrm{MK}-10\left(\mathrm{H}_{4}\right)$, and MK-9 $\left(\mathrm{H}_{4}\right)$. The BLAST analysis of $16 \mathrm{~S}$ rRNA gene sequence of strain KM3-1 indicated that the strain was closely related to $M$. maritima (99.79\% similarity) as shown in Table 1. Phylogenetic analysis of strain KM3-1 revealed that it was belonged to $M$. maritima (Songsumanus et al., 2013) (Figure 1).

\section{Antimicrobial activity of isolates}

All isolates exhibited no antimicrobial activity against E. coli ATCC 25922, S. aureus ATCC 25923, P. aeruginosa ATCC 27853 and C. albicans ATCC 10231, except strains BTG7-3 and BTG10-2 isolated from soils in Narathiwat province that showed activity against $B$. subtilis ATCC 6633 and K. rhizophila ATCC 9341 (Table 2).

In this study, the peat swamp forest soil contained $\mathrm{pH}$ ranged from 3.39 to 6.37 and the most soil samples are rather acidic $\mathrm{pH}$ (Table 1). M. narathiwatensis, M. chalcea, M. humi,
M. aurantiaca and M. maritima strains were isolated and only $M$. humi strains exhibited antimicrobial activity against Grampositive bacteria. The strains of $M$. chalcea are reported to produce antlermicins and tetrocarcins (aminoglycosides) and izumenolide (lactones) that exhibited antibacterial and anticancer activity (Kobinata et al., 1980a; 1980b; Liu et al., 1980; Tomita et al., 1980a; 1980b). Therefore, the further study on the secondary metabolites and biological activity of $M$. humi strains are required. Micromonospora strains produced many kinds of antibiotics including aminoglycosides, ansamysins, cyclic depsipeptide, dibenzazepines, diketopiperazine, dipeptides, echinosporamicin, furan, indolocarbazole alkaloids, lactones, macrolides, naphthoquinones, polypeptide, pyrazines, quinone, quinocycline, tetrocarcin, and other new compounds. Antibacterial, antifungal, anticancer, antitumor, anti-inflammatory, antiparasitic activity, cytostatic effects and trehalase glycosidase inhibitor activity are presented as their biological activity (Boumehira et al., 2016).

\section{CONCLUSION}

As part of the research on screening of actinomycete strains from soils in peat swamp forests collected in Narathiwat, Pattaloong and Yala provinces, thirteen isolates including, M. narathiwatensis strains were distributed in Narathiwat, Patthaloong, Yala provinces, the strain of Micromonospora chalcea was found in Yala, Micromonospora humi, Micromonospora aurantiaca strains were distributed in Narathiwat and Patthaloong provinces, while Micromonospora maritima strain was distributed in Patthaloong province. Two isolates in Group 4 expressed antimicrobial activity against Bacillus subtilis ATCC 6633 and Kocuria rhizophila ATCC 9341. This evidence showed that the new soil sources are useful for the investigation of new microorganisms and their secondary metabolites.

\section{FINANCIAL SUPPORT AND SPONSORSHIP}

This study was supported by the Research Grant of Faculty of Pharmaceutical Sciences, Chulalongkorn University and the scholarship from the Royal Golden Jubilee Ph.D. Program to $\mathrm{C}$. T.

\section{CONFLICT OF INTERESTS}

There are no conflicts of interest.

\section{ACKNOWLEDGMENTS}

The authors thank M. Chijimatsu and H. Morishita, Research Resources Center, the RIKEN Brain Science Institute (BSI), for the analysis of cell wall peptidoglycan components.

\section{REFERENCES}

Acar JF, Goldstein FW. 1991. Disk susceptibility testing. In: Lorian V. ed. Antibiotics in Laboratory Medicine $3^{\text {rd }}$ ed. Baltimore, MD: Williams and Wilkins 17-52.

Ara I, Kudo T. Two new species of the genus Micromonospora: Micromonospora chokoriensis sp. nov. and Micromonospora coxensis sp. nov., isolated from sandy soil. J Gen Appl Microbiol, 2007; 53:29-37.

Arai T. 1975. Culture media for Actinomycetes. The Society for Actinomycetes, Japan, p.1-31.

Boumehira AZ, El-Enshasy HA, Hacène H, Elsayed EA, Aziz R, Park EY. Recent progress on the development of antibiotics from the genus Micromonospora. Biotechnol Bioprocess Eng, 2016; 21:199-223. 
Brock TD, Madigan MT, Martinko JM, Parker J. 1993. Biology of microorganisms. New Jersy: Prentice Hall.

Collins MD, Pirouz T, Goodfellow M, Minnikin DE. Distribution of menaquinones in actinomycetes and corynebacteria. J Gen Microbiol, 1977; 100:221-230

Felsenstien J. Confidence limits on phylogenies: an approach using the bootstrap. Evolution, 1985; 39:783-791.

Garcia LC, Martínez-Molina E, Trujillo ME. Micromonospora pisi sp. nov., isolated from root nodules of Pisum sativum. Int J Syst Evol Microbiol, 2010; 60:331-337.

Willey and Sons.

Glasby JS. 1993. Encyclopedia of Antibiotics. Chichester: John

Hirsch P, Mevs U, Kroppenstedt RM, Schumann P, Stackebrandt E. Crytoendolithic actinomycetes from Antarctic sandstone rock samples: Micromonospora endolithica sp. nov. and two isolates related to Micromonospora coerulea Jensen 1932. Syst Appl Microbiol, 2004; 27:166-174.

Huang HLJ, Hu Y, Fang Z, Zhang K, Bao S. Micromonospora rifamycinica sp. nov., a novel actinomycete from mangrove sediment. Int $\mathrm{J}$ Syst Evol Microbiol, 2008; 58:17-20.

Jongrungruangchok S, Tanasupawat S, Kudo T. Micromonospora krabiensis sp. nov., isolated from marine soil in Thailand. J Gen Appl Microbiol, 2008; 54:127-133.

Kasai H, Tamura T, Harayama S. Intrageneric relationships among Micromonospora species deduced from gyrB-based phylogeny and DNA relatedness. Int J Syst Bacteriol, 2000; 50:127-134.

Kawamoto I. 1989. Genus Micromonospora. In: Williams ST, Sharpe ME, Holt JG, eds. Bergey's Manual of Systematic Bacteriology, vol. 4, Baltimore: Williams \& Wilkins 2442-2450.

Kelly KL. 1964. Inter-Society Color Council - National Bureau of Standards Color Name Charts Illustrated with Centroid Colors. Washington, DC: US Government Printing Office.

Kimura M. A simple method for estimating evolutionary rates of base substitutions through comparative studies of nucleotide sequences. J Mol Evol, 1980; 16:111-120.

Kobinata K, Uramoto M, Mizuno T, Isono K. Antlermicins B and C, new members of the antlermicin family. J Antibiot, 1980a; 33:772775 .

Kobinata K, Uramoto M, Mizuno T, Isono K. A new antibiotic, antlermicin A. JAntibiot, 1980b; 33:244-246.

Lane DJ. 1991. 16S/23S rRNA sequencing. In: Stackebrandt E, Goodfellow M, eds. Nucleic Acid Techniques in Bacterial Systematics. Chichester: Wiley 115-148.

Liu WC, Astle G, Wells JS, Trejo Jr. WH, Principe PA, Rathnum ML, Parker WL, Kocy OR, Sykes RB. Izumenolide-a novel beta-lactamase inhibitor produced by Micromonospora. I. Detection, isolation and characterization. J Antibiot, 1980; 33:1256-1261.

Minnikin DE, O'Donnell AG, Goodfellow M, Alderson G, Athalye M, Schaal A, Parlett JH. An integrated procedure for the extraction of bacterial isoprenoid quinones and polar lipids. J Microbiol Methods, $1984 ; 2: 233-241$

Phongsopitanun P, Kudo T, Ohkuma M, Pittayakhajonwut P, Suwanborirux K, Tanasupawat S. Micromonospora sediminis sp. nov., isolated from mangrove sediment. Int. J. Syst. Evol. Microbiol., 2016; 66:3235-3240.

Posa MRC, Wijedasa LS, Corlett RT. Biodiversity and conservation of tropical peat swamp forests. BioScience 2011; 61:49-57.

Saito N, Nei M. The neighbor-joining method: a new method for reconstructing phylogenetic trees. Mol Biol Evol, 1987; 4:406-425.

Sasser M. 1990. Identification of bacteria by gas chromatography of cellular fatty acids, MIDI Technical note 101. Newark, DE: MIDI Inc.

Shirling E B, Gottlieb D. Methods for characterization of Streptomyces species. Int J Syst Bacteriol, 1966; 16:313-340.

Songsumanus A, Tanasupawat S, Igarashi Y, Kudo T. Micromonospora maritima sp. nov., isolated from mangrove soil. Int J Syst Evol Microbiol, 2013; 63:554-559.
Songsumanus A, Tanasupawat S, Thawai C, Suwanborirux K, Kudo T. Micromonospora humi sp. nov., isolated from peat swamp forest soil. Int J Syst Evol Microbiol, 2011; 61:1176-1181.

Staneck JL, Roberts GD. Simplified approach to identification of aerobic actinomycetes by thin-layer chromatography. Appl Microbiol, 1974; 28:226-231.

Sveshnikova MA, Maksimova TS, and Kudrina ES. The species belonging to the genus Micromonospora Ørskov, 1923 and their taxonomy. Mikrobiologiya, 1969, 38:754-763.

Tamaoka J, Komagata K. Determination of DNA base composition by reversed-phase high-performance liquid chromatography. FEMS Microbiol Lett, 1984; 25:125-128.

Tamura K, Stecher G, Peterson D, Filipski A, Kumar S. MEGA6: Molecular evolutionary genetics analysis version 6.0. Mol Biol Evol, 2013; 28:2731-2739.

Tanasupawat S, Jongrungruangchok S, Kudo T. Micromonospora marina sp. nov., isolated from sea sand. Int J Syst Evol Microbiol, 2010; 60:648-652

Thawai C, Tanasupawat S, Itoh T, Suwanborirux K, Kudo T. Micromonospora eburnea sp. nov., isolated from a Thai peat swamp forest Int J Syst Evol Microbiol, 2005a; 55:417-422.

Thawai C, Tanasupawat S, Itoh T, Suwanborirux K, Kudo T. Micromonospora siamensis sp. nov., isolated from Thai peat swamp forest. Int J Syst Evol Microbiol, 2005b; 51:229-234.

Thawai C, Tanasupawat S, Kudo T. Micromonospora pattaloongensis sp. nov., isolated from a Thai mangrove forest. Int J Syst Evol Microbiol, 2008; 58:1516-1521.

Thawai C, Tanasupawat S, Suwanborirux K, Itoh T, Kudo T. Micromonospora narathiwatensis sp. nov., from Thai peat swamp forest soils. Int J Syst Evol Microbiol, 2007; 53:287-293.

Tomita F, Tamaoki T, Shirahata K, Kasai M, Morimoto M, Ohkubo S, Mineura K, Ishii S. Novel antitumor antibiotics, tetrocarcins. J Antibiot, 1980a; 33:668-6670.

Tomita F, Tamaoki T. Tetrocarcins, novel antitumor antibiotics. I. Producing organism, fermentation and antimicrobial activity. J Antibiot, 1980b; 33:940-945.

Trujillo ME, Kroppenstedt RM, Fernândez-Molinero C, Schumann P, Martínez-Molina E. Micromonospora lupini sp. nov. and Micromonospora saelicesensis sp. nov., isolated from root nodules of Lupinus angustifolius. Int J Syst Evol Microbiol, 2007; 57:2799-2804.

Uchida K, Aida K. An improved method for the glycolate test for simple identification of the acyl type of bacterial cell walls. J Gen Appl Microbiol, 1984; 30:131-134.

Wang C, Xu XX, Qu Z, Wang HL, Lin HP, Xie QY, Ruan JS, Hong K. Micromonospora rhizosphaerae sp. nov., isolated from mangrove rhizosphere soil. Int J Syst Evol Microbiol, 2011; 61:320-324.

Weisburg WG, Barns SM, Pelletier DA, Lane DJ. 16S ribosomal DNA amplification for phylogenetic study. J Bacteriol, 1991; 173:697-703. Williams ST, Cross T. 1971. Actinomycetes. In: Booth C, ed. Methods in Microbiology. London: Academic Press 295-334.

Yoon SH, Ha SM, Kwon S, Lim J, Kim Y, Seo H, Chun J. Introducing EzBio-Cloud: a taxonomically united database of $16 \mathrm{~S}$ rRNA gene sequences and whole-genome assemblies. Int J Syst Evol Microbiol, 2017; 67:1613-1617.

How to cite this article:

Thawai C, Kanchanasin P, Ohkuma M, Kudo T, Tanasupawat $\mathrm{S}$. Identification and antimicrobial activity of Micromonospora strains from Thai peat swamp forest soils. J App Pharm Sci, 2018; 8(04): 119-125. 